\title{
DIGITAL SIGNATURES OF THE BAROQUE
}

THE CULT OF THE CHRONOGRAM IN $18^{\text {TH }}$ CENTURY BOHEMIA

ALEXWENT

The embedding of coded dates (chronograms) in religious and secular memorial inscriptions became something of an obsession in the early 1700s, especially in the Czech lands. This essay proposes a number of possible reasons for the fashion and further suggests that the appeal of the chronogram had less to do with intellectual vanity - though this played a part - and more with the acknowledged power of inscription itself, particularly when it came in the form of a public prayer.

By examining several notable examples, the author seeks to demonstrate that chronograms were more than simply word-games; they provided an essential link between the reader, the context of contemporary intellectual thought, and the classical heritage from which it was descended. 
Five years after moving to the Royal Court of Dresden, the Bohemian-born composer J.D. Zelenka produced a choral mass for his employer, Augustus II, Elector of Saxony. It was the musician's second published work (ZWV $2^{1}$ ) and it survives today only in an incomplete form. On one page of the manuscript the composer has appended his full name in its Latin form:

\section{Ioannes LVCas IgnatIVs DIsMas zeLenka}

The inscription is interesting for two reasons: firstly, Zelenka, a Catholic composer in a newly Catholic court islanded in protestant Saxony, shows his devotion by adding to his birthnames (Lukáš Ignác) the name of Dismas, the 'good thief' of the crucifixion story. Secondly, certain letters are picked out in capitals, highlighting their dual function as Roman numerals, and giving the entire inscription the air of a riddle. And indeed, when added together, these letters give the year of composition:

$$
\mathbf{I}+\mathbf{L}+\mathbf{V}+\mathbf{C}+\mathbf{I}+\mathbf{I}+\mathbf{V}+\mathbf{D}+\mathbf{I}+\mathbf{M}+\mathbf{L}=\mathbf{1 7 1 4}
$$

Such encoded dates - known as 'chronograms' from the Greek for 'time writing' - flourished in eighteenthcentury Europe, particularly on memorials and medals, but also in books and manuscripts. Zelenka's is not only typical of the period and region, but also a pleasing example of the perfection of the art. The accepted system of chronogrammatic encoding depends on an understanding that all letters that can be read as Roman numerals will be included in the final count; it is not considered good practice to be selective. James Hilton, compiler of the magisterial 1882 survey Chronograms, 5000 and More in Number, warns the reader - with typical Victorian severity - that "no such letters may be passed over to suit the convenience of the composer", adding that "surplus letters would assert too much and carry the date beyond its limits."

A further convention dictates that the solution to any given chronogram is arrived at only by mathematical addition; combinations such as 'IV' or 'CM' - in which the smaller numeral precedes the greater, implying subtraction - do not count in these cases. For instance, the 'IV' in 'IgnatIVs' will always be read as 6 and never 4. To create a chronogram that so neatly fits the composer's name is therefore no easy matter. In the example quoted above, Zelenka was fortunate that each of his first three names contained at least one Roman numeral. It is a matter of interest that had he not adopted the name of Saint Dismas, the chronogram would have been 1,501 years short of the correct date. ${ }^{2}$

Word-games evidently appealed to Zelenka, who appears to have been a somewhat introverted character as well as a highly innovative composer. Like his near-contemporary J.S. Bach (the composer of several pieces whose musical notes punned on his surname B-A-C-H) Zelenka plainly took pleasure in the lexical, mathematical, geometrical, and numerological possibilities afforded by the setting to music of certain texts. An example of such playfulness appears in Zelenka's canon for four voices (ZWV 179) composed in 1722, which sets the (appropriate) text "Vide Domine et considera laborem meum" - "See, Lord, and consider my labour". The simplicity of this little piece belies its artful construction: not only do we hear the complex overlaying of voices typical of a canon, but halfway through the piece the melody is reversed, to create an exact musical palindrome, or mirror-image: 


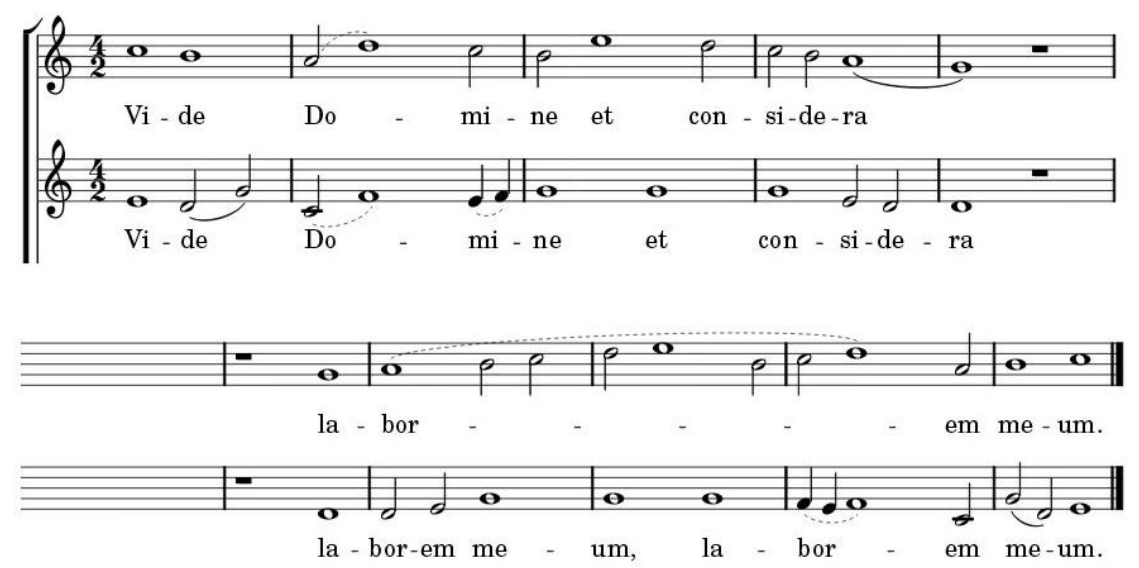

Figure 1

When Zelenka revised his canon six years later for publication by the composer Georg Telemann in the latter's Getreue Musicmeister, a series of singing exercises, he prefaced the work with the following multiple chronogram:

LeCtor MI VIDere LIbet qVae seqVVntVr

VIrtVosI possessorIs honorI apponere ILLa VoLVIt Iohannes DIsMas zeLenka

FIDVs In prInCIpIo In fIne aMICVs et serVVs

DabantVr Vero ILLa In DresDa noVa tertIa aprILIs In abItV soLIs

Reader, it pleases me to see what follows: Johannes Dismas Zelenka - faithful friend and servant

at the beginning and at the end - wished to

attribute these [items] to the honour of their

virtuous possessor, these [items which] were presented

indeed in Dresden at sunset on the third of April

Zelenka openly names the precise date and time of day at which he presented the composition to Telemann (the presumed 'virtuous possessor'). The year, on the other hand, is to be found only by adding the chronogrammatic elements: in each individual line of the dedication; the Roman numerals add up to 1728. The exquisite pleasure that such puzzles give to both setter and solver is part of the process of memorialisation. These coded messages offer to pass on more information than they at first sight reveal. Given sufficient knowledge, the puzzle will last beyond the grave, so long as future generations possess the key.

However, diverting such word-games, though, not everyone was impressed. Contemporaries mocked the intellectual conceit of chronogram-makers. Despite his own skill in Latin verse composition, the English essayist and satirist Joseph Addison, writing in 'The Spectator' of 9 May 1711, sniped at an activity which he considered an inessential display of vanity:

For as some of the Letters distinguish themselves from the rest, and overtop their Fellows, they are to be considered in a double Capacity, both as Letters and as Figures. Your laborious German Wits will turn over a whole Dictionary for one of these ingenious Devices. A Man would think they were searching after an apt classical Term, but instead of that they are looking out a Word that has an $L$, and $M$, or a D in it. When therefore we meet with any of these Inscriptions, we are not so much to look in 'em for the Thought, as for the Year of the Lord. 
Addison's view that chronograms lack imagination - being examples of what he calls 'false wit' - prevails even today: Roy Stokes, in A Bibliographical Companion (1989), is not alone when he writes that chronograms "were not intended to be serious attempts at concealment but solely for mild jocularity".

Yet the sheer abundance of central European chronograms in the seventeenth and eighteenth centuries suggests that the trend was more than simply a private display of intellect by 'German wits'. There were also valid public reasons for chronogrammatic inscriptions, among which are the invocation of God or the saints as protectors, for example in times of plague; and the commemoration of monarchs and nobles as patrons.

\section{WHY BOHEMIA?}

Hilton attributes the best chronogram-making to Zelenka's adopted homeland of Saxony. In fact, as his compendium makes clear, encoded dates started to appear on vernacular architecture between the Rhine and the Danube from the late 1500s onwards. But the real craze appears to have been concentrated in Bohemia, the composer's country of birth, originating in the mid-seventeenth century and reaching its peak in the early-to-mid-eighteenth. I propose a number of reasons for this phenomenon.

Firstly, an emphasis on dedicatory inscriptions - particularly in Latin - coincided with the wave of baroque architecture which dominated Europe during the seventeenth century. In Bohemia, the baroque style was strongly identified with the resurgence of Catholicism after the Thirty Years' War (1618-1648), as evidenced, for example, in the statues erected on Prague's Charles Bridge in the second decade of the eighteenth century. The idea, common in classical and biblical texts, was that 'the stones will speak' ('saxa loquuntur'), with inscriptions below the statues transmitting the truths of their time to future generations. Secondly, Bohemia lay on a fault line between the Holy Roman Empire and that brand of protestantism which had originated in the sermons of reformers including Jan Hus and, later, Martin Luther. Although chronograms were employed by Catholics and Protestants alike, it is tempting to associate their rise with the Europe-wide trend for coding and encryption which grew up as a result of the need to conceal or equivocate in matters of religious faith.

Thirdly, chronogrammatic inscriptions, with their appeal to classical learning and patterning, would have been seen as a representation of the power of God, particularly in those inscriptions where the Roman numerals are both enlarged and picked out in gold. More importantly these academic puzzles would have expressed the power of the Church itself by emphasising the intellectual distance between a book-learned clergy and an ignorant laity. For Anna Kapuścińska and Piotr Urbański, co-authors of a paper on the Lutheran poet Paul Zacaharias, chronograms "seem to work as intellectual stimuli intended to engage the reader in a sort of divine game, which invigorates the mind and aims to inspire righteous thoughts, leading to the spiritual improvement and moral purity".

A supportive context for many, if not all, of the above arguments can be found in the following observation concerning the process of Bohemian re-Catholicization:

The Jesuits ... aimed at optical and content unification of sacred buildings to emphasize true presence of Jesus Christ and all the saints ... [In] a form of sculptural series and architectonically created sceneries they have converted the city - image of the world - into the theatre of the world. [A] new language of architecture, symbols and signs created a true present image in city and above it a mental image of 'Bohemian heaven' based on emphasis on Bohemian patrons. ... The Jesuits introduced the whole system of visual communication through [a] system of signs and symbols.

Blanka Altová: 'The City of Kutná Hora as a Bohemian baroque space' 
Chief among those patron saints was the fourteenth century priest John Nepomuk (Fig. 2, p. 21), whose elevation to the sainthood in the eighteenth century led to a profusion of chronogrammatic outpourings, far more so than to Wenceslas, Agnes, Vojtěch, or other spiritual protectors.

Nepomuk's beatification took place at the height of what might be called a period of chronogram fever in Bohemia; but his popularity as a subject for chronogrammatic treatment may also allude to the arcane circumstances of his martyrdom, which came about because he refused to reveal to Wenceslas IV what the queen had told him in confession. What more appropriate epitaph than a hidden message to commemorate a priest who exercised the right to silence? A typical early example can be seen on the Nepomuk statue in Vršovice, a village which became incorporated into the city of Prague at the start of the twentieth century. A mirror image of Jan Brokoff's statue of the same saint on the Charles Bridge produced in 1683, this less well-known version of two years later is one of the oldest extant religious artefacts in the locality.

Carved into the pedestal of the statue is the following memorial inscription, which translated reads "The town of Vršovice consecrated [this statue] to Saint John Nepomuk, special defender of their homeland":

\title{
SANCTO IOANNI NEPOMVCENO SPECIALI PATRIAE PATRONO CIVITAS VRSOVICENSIS SACRAVIT
}

Although in this comparatively crude carving the all-important Roman numerals are not elevated in any special way, and they still operate according to the acknowledged principles of chronograms outlined above, resulting in this case in the year of construction:

\section{II MVC CILI I CIVI VVICI CVI $=1685$}

Nepomuk was finally beatified by the recently-elected Pope Innocent XIII on 31 May 1721, an event recorded on a number of medallions struck especially for the occasion. One shows the Church and Bohemia personified on either side of an altar, with the inscription:

\section{Vno Is CLeMentIs sVb sIDere fVLsIt In arIs (=1721)}

\author{
"He shone upon the altars under the single star of Clement" \\ (a reference to the papal arms of Innocent's predecessor)
}

As a key weapon in the arsenal of the Counter-Reformation, further statues of Nepomuk, many of them likewise adorned with chronograms, were set up throughout Bohemia as well as in Italy, Germany, Lithuania, and Poland. Comprehensive illustrated catalogues featuring multiple examples can be found online. ${ }^{3}$

Of all the chronogrammatic art in Bohemia, perhaps the most celebrated example is the plague column of Kutná Hora (Kuttenberg), an important city to the east of Prague which was home to the Royal Mint and a renowned silver mining town. The seventeen metre column was conceived by the Jesuit sculptor František Baugut. Its foundation stone was laid on 15 June 1714, and the dedication took place eighteen months later on 15 December 1715.

Baugut's curious, organic sculpture fulfils numerous simultaneous functions. As it ascends through multiple twisted tiers, it acts as a memorial to the dead of the plague of 1713, a celebration of the city's mining industry, and a propitiation in stone to the saints of Bohemia, and to the Mother of God in particular. Centrally placed on the column is a lengthy dedication to the Virgin Mary. As with the Vršovice statue, the town itself is named as the donor: 


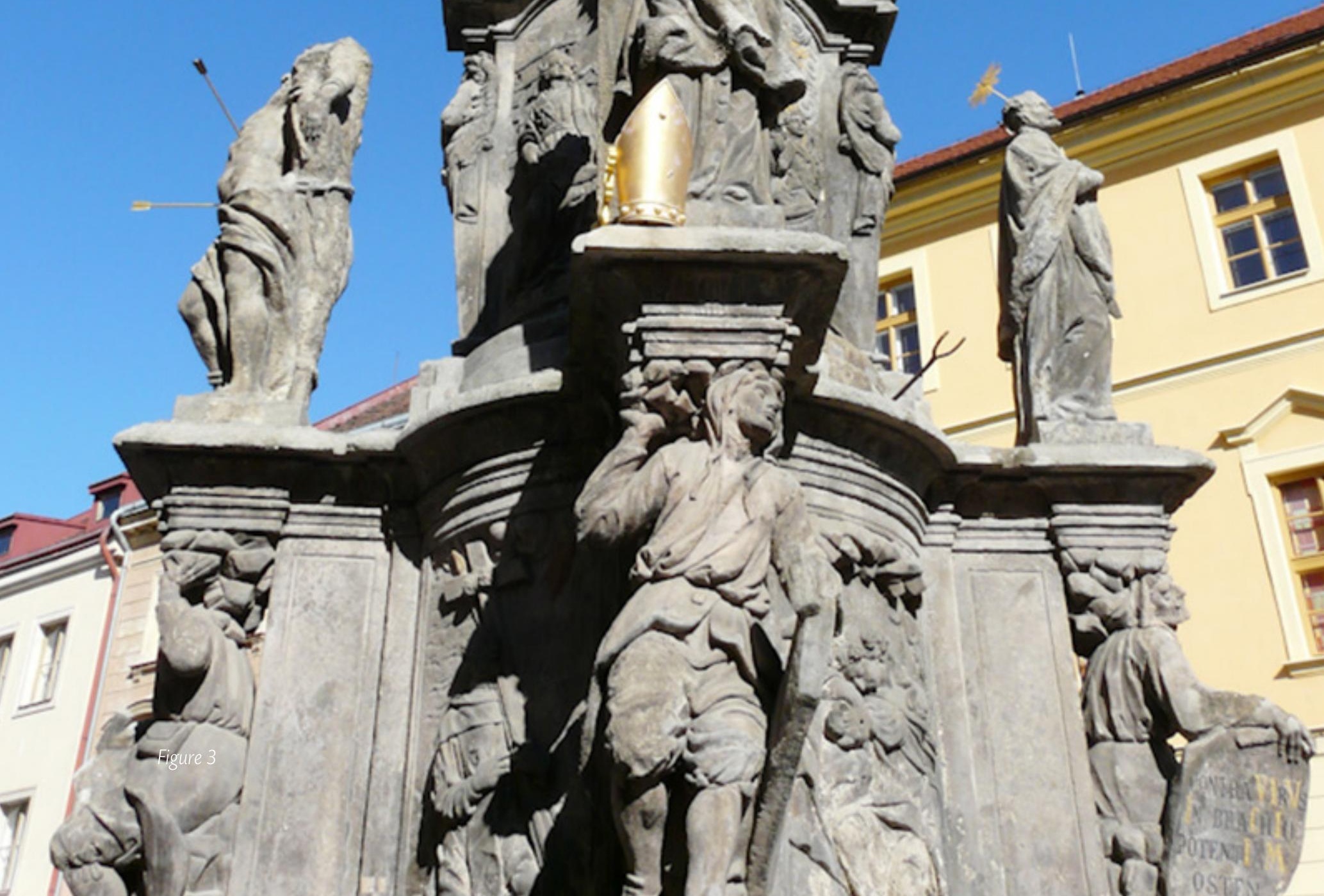




$$
\begin{aligned}
& \text { ATR } E \div=2 \text { ? } \\
& \text { SE PER RG } \\
& S N E \text { NA } 0 \\
& \text { ONCEPTA } \\
& \text { R TE POS T } \\
& \text { EP E. A E } \\
& \text { BERATA } \\
& \text { AR AN S GRAT S } \\
& \text { I. } \mathrm{OT} A
\end{aligned}
$$

1.

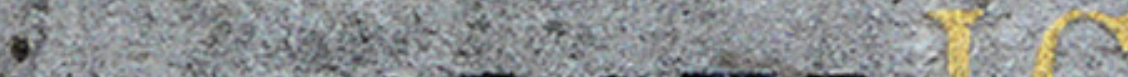
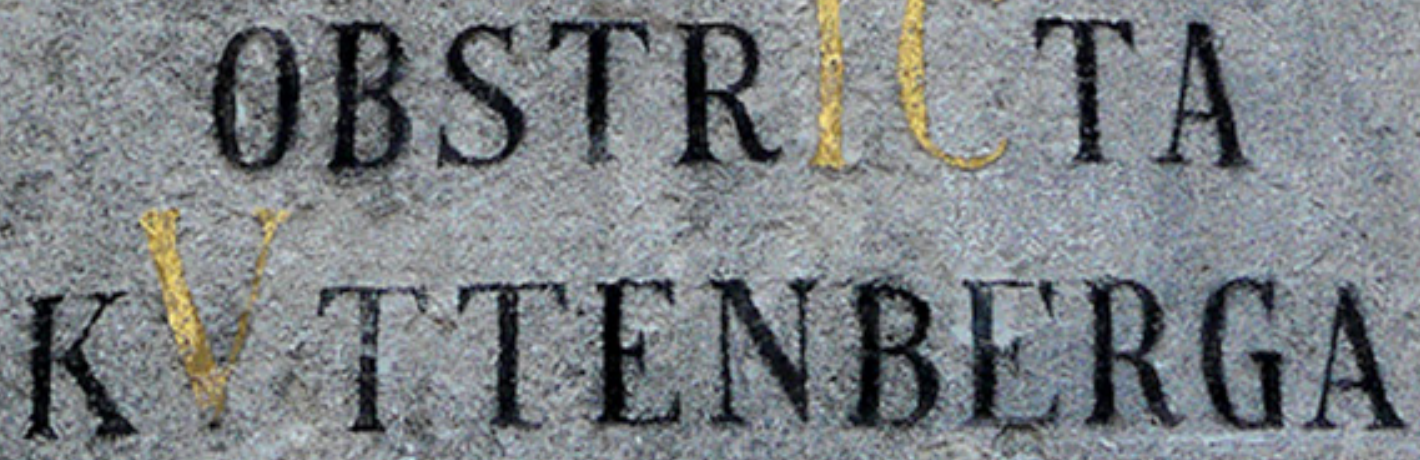


\title{
MatrI DeI | seMper VIrgInI | sIne naeVo | ConCepta | rIte posVIt epIDeMICa LVe | LIberata | MarIanIs gratIIs | DeVota | aC obstrICta | kVttenberga (= 6146)
}

The devoted and dutiful Kuttenberg, liberated from the epidemic by Mary's grace, ceremonially placed (this monument) to the Mother of God, ever the Virgin, the immaculate conception.

In this case, the chronogram reveals not a calendar year, but instead a tally of 6,146 - usually taken to indicate the number of plague victims. Below the main inscription, four kneeling miners at each corner carry shields with their own inscriptions, indicating the years of the column's foundation and dedication:

\section{De MortIs teLo ${ }^{4}$ In proprIo VVLnere ConfregIt}

Through His own wounds He has snapped in sunder the arrow of death (=1714)

pestIferos LIbItIno Morbe De VLCere sanaVIt

He has cured those plagued with death from the sickly ulcer (=1715)

\section{Contra VIrVs In braChIo potentIaM ostenDIt}

He has shown strength with His arm against the plague (=1715)

\author{
gLorIosa poenItentIa pesteM LoCI DetVrbaVIt
}

WIth glorious penitence He has toppled the plague in (this) place (=1715)

Repeated chronograms of this type - usually one on each face of the column's pedestal - are not unusual in the Czech lands. Similar examples survive on the plague column in Prague's Malostranské náměstí (1713), the Nepomuk memorial column in Brno (1729), and the Holy Trinity column in Olomouc (1754). Whichever way you face, the plague is there.

\section{'TIME HAS TRANSFIGURED THEM INTO UNTRUTH'}

It is particularly striking that the Kutná Hora verses closely mirror the liturgical text of the Magnificat ('Fecit potentiam in brachio suo': 'He hath shown strength with His arm') and Psalm 76 ('ibi confregit potentias arcuum telum': 'There broke He the arrows of the bow'). The implication is that the subject of each of the four sentences should be taken to be Almighty God. Surprisingly, one recent paper ${ }^{5}$ suggests that the sculptor himself is the subject of the first verse, concluding that Baugut must have succumbed to, and subsequently recovered from, the plague. The same paper goes on to make the equally unusual claim that 1715 refers not to the year of the column's completion, but to the number of citizens who rallied from the plague, a misconception that has since taken root in a number of online guides to the town.

It is a matter of regret that what little serious research there is on the plague column tends to perpetuate similar errors and assumptions. In his 1887 Guide to Kutná Hora and its surroundings, the historian Petr Miloslav Veselský not only miscalculates these same chronograms (finding, instead of 1715, the years 1615 and 1710); he also postulates instead of 'Confregit' the nonsensical 'Corn Eregit', leading to the somewhat unlikely interpretation that a certain 'Korn' [sic] erected the column. Such mistakes are not confined to modern commentators. When in 1667 the Holy Roman Emperor Leopold I arranged for a copy to be made of the Marian column in Vienna, the part of the chronogram containing the title of his father Ferdinand III was changed from 'fernanDVs tertIVs' to 'fernanDVs III', inadvertently subtracting three years from the correct date. 
These errors of reading call to mind the poem 'An Arundel Tomb' by the English poet Philip Larkin. In it, he bemoans the fact that those living in today's 'unarmorial age' lack the necessary skills to interpret memorial inscriptions with any degree of accuracy. As he examines the memorial effigy of the tenth earl of Arundel and his wife lying 'side by side', the poet remarks

\author{
Such faithfulness in effigy \\ Was just a detail friends would see: \\ A sculptor's sweet commissioned grace \\ Thrown off in helping to prolong \\ The Latin names around the base.
}

As Larkin understands only too well, leaving messages for posterity is an essential act of cultural transmission. Yet, however permanent the inscription - and memorials have outlasted many a marriage - the message of the couple's fidelity is effective only so long as it is 'read' correctly; otherwise they may as well be 'lying' in stone as well as lying in stone. We have come to a point in history, Larkin says, where people can no longer be certain of the past because they have lost the key to interpret it:

\author{
They would not guess how early in \\ Their supine stationary voyage \\ The air would change to soundless damage, \\ Turn the old tenantry away; \\ How soon succeeding eyes begin \\ To look, not read.
}

\title{
CONCLUDING REMARKS
}

The fashion for chronograms lasted for only a century or so, with the majority composed between the end of the seventeenth century and the middle of the eighteenth. These carefully-contrived puzzles combined an intellectual appeal (for Protestants and Catholics alike) with a decorative function that sat easily within the aesthetic of the late Baroque. The statues of Bohemia, and those manuscripts which - like Zelenka's - happily survive, originated in a world where religion and philosophy combined to win souls and minds; a world whose artefacts artists hoped to preserve against the ravages of time by stamping them, paradoxically, with a concealed date. The composers of Bohemia's thousands of chronograms must have lived and died in the hope that their mysterious, cabbalistic, transformation of texts into numerical codes would assert the power of divine thought for ever.

Ironically, just as any inscription is both a mark of confidence in one's own artistry and at the same time an admission that all such art will turn to dust ('Look on my works, ye Mighty, and despair!'), so these elaborately-wrought riddles, which seemed to be written for all time, have become little more than an oblique footnote in today's less questioning age. But without them our understanding of Bohemia during a crucial period in its religious and architectural history would be considerably impoverished.

\section{ACKNOWLEDGEMENTS}

Thanks to John Godwin and Matthew Clark for their assistance in translation. For theories surrounding Zelenka's use of chronograms, see the discussion by the present author and others at: http://www.jdzelenka. net/forums/archive/index.php/t-127.html 


\section{NOTES}

${ }^{1}$ Zelenka's compositions are traditionally identified by the letters ZWV (Zelenka Werkverzeichnis) and a number, indicating their position in the catalogue edited by Wolfgang Reiche.

2 So-called 'pure chronograms' contain one numeral per word, while 'natural chronograms' read sequentially from the largest available number to the smallest. Both forms are rare. The well-known and rather beautiful English example on the death of Elizabeth 'My Day Closed Is In Immortality' - which counts only the initial letters in sequence to form the year 1603

- is not a true chronogram since it contains additional Roman numerals such as the two 'm's in 'Immortality'.

${ }^{3}$ The fullest list of chronograms in Bohemia is to be found at http://geo.mff.cuni.cz/latina/, with a subsection devoted to John Nepomuk at http://geo.mff.cuni.cz/latina/svJanove.htm. A catalogue of Polish Nepomuk statues and chronograms is to be located at http://nepomuki.pl/nepomuk/chrono.htm

${ }^{4}$ It is a matter of considerable interest that in order to ensure a viable numerical solution, chronograms frequently exhibit grammatical emendations or corruptions. In the first of the above verses, for example, we find 'telo' instead of the expected 'teluM', whose accusative ending would give the wrong answer.

${ }^{5}$ Oravova, Lenka,'František Baugut a jeho dílo na kutnohorsku' (Brno, 2007), p. 23: "Dozvídáme se z nich datum vročení sousoší (1714), údaje o počtu obětí (6146) a uzdravených (1715) a s textem, ze kterého vyplývá, že Baugut byl v roce 1714 morem také nakažen, ale uzdravil se."

\section{REFERENCES}

Addison, J. (1711) 'The Spectator' no. 60

Altová, B. (2009) The City of Kutná Hora as a Bohemian baroque space. Available at: http://lidemesta.cz/archiv/ cisla/11-2009-1/mesto-kutna-hora-jako-cesky-barokni-prostor.html (Accessed: 20 April 2016)

Hilton, J. (1882-5) Chronograms, 5000 and More in Number.

Kapuścińska, A. and Urbański, P. (2013) 'Poesis Artificiosa ad Gloriam Dei: Paul Zacharias and his Disticha Sacra', in Poesis Artificiosa. Between Theory and Practice.

Keyssler, J.G. (1760) Travels through Germany, Bohemia, Hungary, Switzerland, Italy and Lorrain.

Larkin, P. (1964) 'An Arundel Tomb', in The Whitsun Weddings.

Louthan, H. (2011) Converting Bohemia: Force and Persuasion in the Catholic Reformation. Cambridge: Cambridge University Press.

Oravová, L. (2007) 'František Baugut a jeho dílo na kutnohorsku'

Seifert, O. and Mottlová, N. (2014) Kutnohorské sochy světců.

Slouka, J. (2010) Mariánské a morové sloupy Čech a Moravy

Stockigt, J.B. (2000) Jan Dismas Zelenka: A Bohemian Musician at the Court of Dresden. Oxford: Oxford University Press.

Stokes, R. (1989) 'A Bibliographical Companion', Current Research in Library and Information Science, 10, p. 184.

Veselský, P.M. (1877, reprinted 1999), Průvodce po kr. horním městě Hoře Kutné a nejbližším okolí

IMAGES

FIGURE 1: Zelenka: Vide Domine (ZWV 179)

FIGURE 2: Brokoff: Saint Jan Nepomuk (copy, 1685, Saint Nicholas Church Vršovice) photograph by the author

FIGURE 3,4,5: Plague column at Kutná Hora, photographs by the author 